\title{
Knowledge, Attitude and Practice towards COVID-19 among Dental Practitioners in Bhutan
}

\author{
PRATAP SINGH TAMANG ${ }^{1}$, GYAN PRASAD BAJGAI', DORJI PHURPA', SONAM NGEDUP', HARI PRASAD POKHREL² (DD
}

INTRODUCTION: Corona virus disease was first reported in Wuhan city of China in 2019. The disease is caused by a highly infectious virus which can be transmitted from human to human through physical contact, droplets, or touching surfaces contaminated with the virus.

AIM: The study aims to get an assessment of knowledge, attitude and practices towards COVID-19 disease among the dental practitioners in Bhutan.

MATERIAL AND METHODS: An online cross- sectional study was conducted among dental practitioners working in different hospitals across the country. All dental professionals who provided their email address were included in the study. Data were collecting using a structured questionnaire shared though email. A total of 157 dental professionals were invited through e-mail to participate in the study.

RESULTS: A total of 125 dental professionals participated in the study (response rate 79.6\%). Over half of the participants (51.2\%) were between the age group 20-30 years. Despite almost everyone (98.4\%) knowing the causative agent and management of COVID-19 positive patients, only around a half of the participants (48\%) had a good level of knowledge on COVID-19.

CONCLUSION: The study found that less than half of the participants have a good level of knowledge on COVID-19 while a majority of them feel that there is discrimination against COVID-19 positive patients and health professionals working for COVID-19 patients. The study highlights the need to conduct sensitization, trainings or CME on COVID-19 periodically to keep all health professionals updated with latest advancements to help maintain safety in clinical practice.

KEYWORDS: Bhutan, COVID-19, Dental practitioners, Knowledge, Practice

\section{INTRODUCTION}

Corona virus disease was first reported in Wuhan city of China in 2019. ${ }^{1}$ The virus came into limelight when atypical cases of patients suffering from pneumonia like illness was reported in Wuhan. ${ }^{2}$ One such patient who suffered pneumonia was admitted to one of the hospitals who was later confirmed to be affected by corona virus, specifically $\beta$-coronavirus 2019-nCov.3,4 The virus was identified and named as SARS-Cov-2 on 11th February 2020 and the disease as Corona Virus Disease (COVID-19) by the World Health Organization (WHO). 3 A month later, on 11th March 2020 it was declared as a pandemic by WHO. ${ }^{5}$

The most common symptoms of the disease are high fever, dry cough, sneezing, fatigue, loss of smell, difficulty in breathing, body aches and chest pain among others. The virus can be transmitted to humans from animals where it mutates and can be transmitted from humans to humans through physical contact, droplets, or touching surfaces contaminated with the virus. ${ }^{6,7}$ Its transmission is rapid and these modes have been established. ${ }^{6}$ Droplets can travel up to 6 feet and the virus remains active and contagious, suspended in the air for up to 4 hours. ${ }^{7}$ These droplets can settle on the surfaces which in turn can infect people who handle them. A person gets infected if they touch the surfaces contaminated by the virus and then touch eyes, nose, mouth or any other mucous membranes. ${ }^{7}$ Therefore, washing hands frequently with soap and water or alcohol based hand rubs have been recommended to prevent infection by health experts including the WHO. ${ }^{8}$

In Bhutan first positive case of COVID-19 was detected on $5^{\text {th }}$ March, 2020. The country experienced two national lockdowns; first lockdown from 11th August 2020 which lasted for 21 days and second lockdown from $20^{\text {th }}$ December 2020 till $31^{\text {st }}$ January 2021 for 43 days in a stretch due to sporadic community transmission. The lockdowns helped curb the community transmission which was controlled very effectively. As of $1^{\text {st }}$ March, 2021 the country recorded a total of 867 confirmed cases with 865 being declared recovered and one death taking the recovery rate to $99.8 \% .9$

It is important for health professionals to keep themselves abreast with the latest updates on COVID19 in order to prevent and contain the disease. Assessment of knowledge, attitude and practices (KAP) on COVID-19 among dental practitioners is important due to nature of work and close proximity of the 
working environment. Therefore, such studies are being conducted to obtain accurate information about what is known, believed or practiced in a population or community to prevent and fight the disease. ${ }^{10-12}$ It is important to get accurate and timely information about this infectious disease so that people do not panic during the pandemic and are well prepared to overcome it. Sharing confusing or wrong information during pandemic can lead to unnecessary panic and distress. ${ }^{12}$ Therefore, KAP is crucial for the understanding of peoples' level of knowledge and attitudes and practices towards COVID-19. ${ }^{13}$ This study aims to describe knowledge, attitude and practices regarding COVID-19 among the dental practitioners in Bhutan.

\section{MATERIAL AND METHOD}

A cross-sectional online survey was conducted in February 2021 among dental practitioners working in different hospitals across the country to assess the knowledge, attitude and practices on COVID-19. Data were collecting using a structured questionnaire shared though email. There were a total of 191 dental practitioners in the country during the conduct of this study. Dental professionals not willing to share their email address and those without email address were excluded from the study. A total of 157 (82.2\%) dental professionals working across the country provided their email address and were invited through e-mail to participate in the study. Informed consent form was included at the beginning of the online survey and those responding to questionnaire were assumed to have consented for the study. Data management was done using Microsoft Excel and analyzed using SPSS. The findings are presented as frequency and percent. Mean and standard deviations also have been presented wherever applicable. Knowledge is categorized as 'good', 'moderate' and 'poor' depending on the total score of the participant using Benjamin Bloom criteria. Ethical clearance was granted by the Research Ethics Board of Health (REBH), Ministry of Health, Bhutan (Approval No. REBH/Approval/2020/xo6).

\section{RESULTS}

A total of 125 dental professionals participated in the study (response rate $79.6 \%$ ). Over half of the participants (51.2\%) were between the age group 20-30 years. Around a half of the participants (49.6\%) did not attend sensitization meeting/ CME on COVID-19 and over a half (52.8\%) of them reported that COVID-19 financially affected them. Only around one-fifth
(22.4\%) of the participants followed Ministry of Health/Prime Minister's Office for updates on COVID19 (table 1).

\begin{tabular}{|c|c|c|c|}
\hline VARIABLES & CATEGORY & FREQUENCY & PERCENT \\
\hline \multirow{4}{*}{ Age } & $20-30$ & 64 & 51.2 \\
\hline & $31-40$ & 43 & 34.4 \\
\hline & $41-50$ & 14 & 11.2 \\
\hline & 51 and above & 4 & 3.2 \\
\hline \multirow{2}{*}{ Sex } & Male & 62 & 49.6 \\
\hline & Female & 63 & 50.4 \\
\hline \multirow{4}{*}{ Designation } & Dental Specialist & 6 & 4.8 \\
\hline & Dental Surgeon & 38 & 30.4 \\
\hline & Dental Hygienist & 58 & 46.4 \\
\hline & Dental Technician & 23 & 18.4 \\
\hline \multirow{6}{*}{$\begin{array}{l}\text { Clinical Work } \\
\text { Experience }\end{array}$} & Less than 1 year & 3 & 2.4 \\
\hline & 1 - 5 years & 54 & 43.2 \\
\hline & $6-10$ years & 29 & 23.2 \\
\hline & $11-15$ years & 18 & 14.4 \\
\hline & $16-20$ years & 6 & 4.8 \\
\hline & More than 20 years & 15 & 12 \\
\hline \multirow{2}{*}{$\begin{array}{c}\text { Attended } \\
\text { COVID-19 } \\
\text { sensitization } \\
\text { meeting/ CME }\end{array}$} & Yes & 63 & 50.4 \\
\hline & No & 62 & 49.6 \\
\hline \multirow{5}{*}{$\begin{array}{l}\text { Source of } \\
\text { update on } \\
\text { COVID-19 }\end{array}$} & Newspapers & o & o \\
\hline & Television & 3 & 2.4 \\
\hline & MOH/PMO & 28 & 22.4 \\
\hline & Social media & 12 & 9.6 \\
\hline & All of above & 82 & 65.6 \\
\hline \multirow{2}{*}{$\begin{array}{l}\text { Did COVID-19 } \\
\text { financially } \\
\text { affect you? }\end{array}$} & Yes & 66 & 52.8 \\
\hline & No & 59 & $47 \cdot 2$ \\
\hline \multirow{2}{*}{$\begin{array}{l}\text { Did COVID-19 } \\
\text { psychologically } \\
\text { affect you? }\end{array}$} & Yes & 88 & 70.4 \\
\hline & No & 37 & 29.6 \\
\hline
\end{tabular}

Table 1. Sociodemographic Characteristics $(n=125){ }^{*} \mathrm{MOH} / \mathrm{PMO}$ : Ministry of Health/Prime Minister's Office

Correct responses to knowledge questions have been presented in table 2. Almost everyone (98.4\%) the causative agent of COVID-19 and management of COVID-19 positive patients. However, only around one fourth $(26.4 \%)$ had an idea about the clinical 


\begin{tabular}{|c|c|c|}
\hline QUESTIONS & FREQUENCY & PERCENT \\
\hline What is causative agent of COVID-19? & 123 & 98.4 \\
\hline The clinical symptoms of COVID-19 are & 33 & 26.4 \\
\hline The mode of transmission of COVID-19 & 108 & 86.4 \\
\hline COVID-19 is riskier to people who are & 124 & 99.2 \\
\hline Which age group is affected the most from COVID-19? & 89 & 71.2 \\
\hline How many hours can COVID-19 can survive outside the body? & 44 & 35.2 \\
\hline The new strain of COVID-19 is B117 & 104 & 83.2 \\
\hline The new strain of COVID-19 (B117) is 70\% less infectious than of earlier strain & 101 & 80.8 \\
\hline $\begin{array}{l}\text { At present, there is no effective cure for COVID-19, but early symptomatic and } \\
\text { supportive treatment can help most patients recover from the infection }\end{array}$ & 123 & 98.4 \\
\hline We already have vaccine to prevent COVID-19 & 71 & 56.8 \\
\hline
\end{tabular}

Table 2. Correct responses to knowledge questions $(n=125)$

symptoms and around one-third (35.2\%) were aware of the life span of virus outside the body. Around $10 \%$ of the participants had a poor level of knowledge and less than a half of them (48\%) had a good level of knowledge on COVID-19 (tablez).

\begin{tabular}{|c|c|c|}
\hline $\begin{array}{c}\text { LEVEL OF } \\
\text { KNOWLEDGE }\end{array}$ & 9.6 \\
\hline Poor (0-5 scores) & 12 & 42.4 \\
\hline Moderate (6-7 scores) & 53 & 48.0 \\
\hline Good (8 and above) & 60 & PERCENT \\
\hline \multicolumn{2}{|c|}{ Mean:7.32, SD:1.28, Median: 7} \\
\hline
\end{tabular}

Table 3. Level of Knowledge $(n=125)$

Attitude of participants towards COVID-19 is presented in table 4. A majority of the participants $(89.6 \%)$ reported that they are scared of human to human transmission of COVID-19 and discrimination against COVID-19 positive patients and health professionals working for COVID-19 patients (86.4\%). All the participants agreed that avoiding crowded places would help to prevent COVID-19 infection. However less than half (48\%) reported that COVID-19 will be successfully controlled in dental clinic or laboratory.

Practices of dental professionals to prevent COVID-19 is presented in table 5. Almost everyone (97.6\%) followed cough etiquettes and a majority (92.8\%) of the participants' practices hand hygiene. However, only around two-third (69.6\%) of dental professionals used
PPE during dental procedures and only around $60 \%$ of the participants disseminated information on COVID19 prevention to patients visiting them.

\section{DISCUSSION}

The study found that less than half of the participants had a good level of knowledge on COVID-19 disease. This corresponds to findings reported by studies conducted in other countries which have reported that dental professionals had insufficient knowledge on COVID-19 disease and disinfection processes. ${ }^{14,15}$ Contrary to this, a global study among dental professionals found that dentists had a good level knowledge to deal with COVID-19 disease. ${ }^{16}$ This study found that a majority of the dental professionals feel that there is discrimination against COVID-19 positive patients and health professionals working for COVID19 patients. The working distance for dental personnel is very less with long contact duration which puts them at a higher risk of contracting COVID-19. ${ }^{11}$ Similar findings were reported among medical and dental professionals in Nepal. ${ }^{17}$ The COVID-19 pandemic has shown drastic effects on individuals' social lives, since all sorts of gatherings, social events and even usual hospital cares are closed to reduce the transmission. It has also affected people financially and psychologically. Various preventive measures are put in place including occasional lockdowns to disrupt the transmission chains. ${ }^{18}$

Although the dental professionals had intentions to practice appropriately, some did not have adequate knowledge to implement in practice against COVID 19 disease which was similar to the study by Acharya et al. where $80 \%$ of the participants did not have good 


\begin{tabular}{|c|c|c|c|c|c|c|}
\hline \multirow[t]{2}{*}{ QUESTIONS } & \multicolumn{2}{|c|}{ AGREE } & \multicolumn{2}{|c|}{ DISAGREE } & \multicolumn{2}{|c|}{ UNCERTAIN } \\
\hline & $\mathrm{n}$ & $\%$ & $\mathrm{n}$ & $\%$ & $\mathrm{n}$ & $\%$ \\
\hline Do you agree that COVID-19 is contagious & 122 & 97.6 & 1 & 0.8 & 2 & 1.6 \\
\hline $\begin{array}{c}\text { It is not necessary for younger dental professionals to take measures to } \\
\text { prevent COVID-19 infection }\end{array}$ & 14 & 11.2 & 110 & 88.0 & 1 & 0.8 \\
\hline $\begin{array}{l}\text { Do you agree that COVID-19 infection will be controlled successfully in } \\
\text { Dental clinic or laboratory }\end{array}$ & 60 & 48.0 & 54 & 43.2 & 11 & 8.8 \\
\hline Contacting wild animals would result to COVID-19 infection & 30 & 24.0 & 72 & 57.6 & 23 & 18.4 \\
\hline We should avoid crowded places to prevent COVID-19 infection & 125 & 100 & o & 0.0 & o & 0.0 \\
\hline $\begin{array}{l}\text { Dental professionals who have contact with COVID-19 patients should be } \\
\text { immediately isolated in a proper place for } 21 \text { days observation }\end{array}$ & 116 & 92.8 & 8 & 6.4 & 1 & 0.8 \\
\hline $\begin{array}{c}\text { Do you agree that the virus transmits from animals to humans and vice } \\
\text { versa? }\end{array}$ & 69 & 55.2 & 35 & 28.0 & 21 & 16.8 \\
\hline Are you scared by human-to-human transmission of COVID-19? & 112 & 89.6 & 10 & 8.0 & 3 & 2.4 \\
\hline It is important to create awareness about the COVID-19 in family & 125 & 100.0 & o & 0.0 & o & 0.0 \\
\hline $\begin{array}{c}\text { COVID-19 is generating discrimination against specific groups of people } \\
\text { like COVID-19 positive persons, persons suspected with COVID-19 and } \\
\text { Frontline workers }\end{array}$ & 108 & 86.4 & 13 & 10.4 & 4 & 3.2 \\
\hline
\end{tabular}

Table 4. Attitude(n=125)

knowledge. ${ }^{17}$ Our study found that around $10 \%$ of participants had a poor level of knowledge on COVID19. This is in consistence to the findings reported by many other studies on COVID-19..$^{14,15,17}$ This could be because many participants did not attend the training on COVID-19 disease and/or do not follow media and other COVID-19 related developments. Thus, there is a need to implement activities such as online classes, workshops and trainings to upgrade their knowledge.

Latest guidelines and protocols of Ministry of Health should be made available to all health professionals to stay safe and protect others from becoming infected $(14,18)$. Not being able to include dental professionals 


\begin{tabular}{|c|c|c|c|c|c|c|}
\hline \multirow[t]{2}{*}{ QUESTIONS } & \multicolumn{2}{|c|}{ YES } & \multicolumn{2}{|c|}{ NO } & \multicolumn{2}{|c|}{ SOMETIMES } \\
\hline & $\mathrm{n}$ & $\%$ & $\mathrm{n}$ & $\%$ & $\mathrm{n}$ & $\%$ \\
\hline $\begin{array}{c}\text { Do you wear personal protective equipment (PPE) to prevent COVID-19 } \\
\text { infection during the dental procedures }\end{array}$ & 97 & 77.6 & 8 & 6.4 & 20 & 16.0 \\
\hline $\begin{array}{c}\text { Do you practice } 5 \text { moments of hand hygiene to prevent COVID-19 } \\
\text { infection }\end{array}$ & 116 & 92.8 & 1 & 0.8 & 8 & 6.4 \\
\hline Do you wear a face mask when leaving home/ duty? & 120 & 96.0 & 3 & 2.4 & 2 & 1.6 \\
\hline $\begin{array}{l}\text { Are you disseminating information on preventive measure against COVID- } \\
\qquad 19 \text { to the patients visiting you? }\end{array}$ & 93 & $74 \cdot 4$ & 5 & 4.0 & 27 & 21.6 \\
\hline $\begin{array}{l}\text { Do you follow proper cough etiquettes when you cough or sneeze in clinic, } \\
\text { home, market or in crowd }\end{array}$ & 122 & 97.6 & 1 & 0.8 & 2 & 1.6 \\
\hline $\begin{array}{c}\text { Does all dental healthcare providers in your healthcare facility wear } \\
\text { personal protective equipment (PPE) to prevent COVID-19 infection } \\
\text { during the dental procedures }\end{array}$ & 87 & 69.6 & 15 & 12.0 & 23 & 18.4 \\
\hline $\begin{array}{c}\text { Does all dental healthcare providers in your healthcare facility practice } 5 \\
\text { moments of hand hygiene to prevent COVID -19 infection }\end{array}$ & 92 & 73.6 & 9 & 7.2 & 24 & 19.2 \\
\hline $\begin{array}{l}\text { Does all dental healthcare providers in your healthcare facility wear a face } \\
\text { mask when leaving home/ duty }\end{array}$ & 120 & 96.0 & 1 & 0.8 & 4 & 3.2 \\
\hline $\begin{array}{c}\text { Does all dental healthcare providers in your healthcare facility follow } \\
\text { proper cough etiquettes when you cough or sneeze in clinic, home, market } \\
\text { or in crowd }\end{array}$ & 103 & 82.4 & 4 & 3.2 & 18 & 14.4 \\
\hline $\begin{array}{l}\text { Are all dental healthcare providers in your healthcare facility } \\
\text { disseminating information on preventive measure against COVID-19 to the } \\
\text { patients visiting them }\end{array}$ & 80 & 64.0 & 7 & 5.6 & 38 & 30.4 \\
\hline
\end{tabular}

Table 5. Practice $(n=125)$

without email address and non-response rate of around $20 \%$ were limitations of the study.

\section{CONCLUSION}

The study found that less than half of the participants had a good level of knowledge on COVID-19 while the majority of the participants felt there is discrimination against COVID-19 positive patients and health professionals working for COVID-19 patients. Only around two-third (69.6\%) of the participants used PPE during dental procedures and $60 \%$ of the participants disseminated information on COVID-19 prevention to patients visiting them. The study highlights the need to conduct sensitization, trainings or CME on COVID-19 periodically to keep all health professionals updated with latest advancements and maintain safety in clinical practice.

Acknowledgement: The authors extend their appreciation to all the participants who have contributed their valuable time to make this study successful.

\section{REFERENCES}

1. Shereen MA, Khan S, Kazmi A, Bashir N, Siddique R. COVID-19 infection: Origin, transmission, and characteristics of human coronaviruses. Journal of Advanced Research 2020;24:91-8. https://doi.org/10.1016/j.jare.2020.03.005

2. Li Q, Guan X, Wu P, Wang X, Zhou L, Tong Y, et al. Early Transmission Dynamics in Wuhan, China, of Novel Coronavirus-Infected Pneumonia. The New England Journal of Medicine 2020;382(13):1199-207. https://doi.org/10.1056/NEJMoa2001316

3. World Health Organization (WHO). Naming the coronavirus disease (COVID-19) and the virus that causes it (Online Article). Available from: https://www.who.int/emergencies/diseases/novelcoronavirus-2019/technical-guidance/naming-thecoronavirus-disease-(covid-2019)-and-the-virus-thatcauses-it. [Last Accessed on $11^{\text {th }}$ February, 2021] 4. Guan W-j, Ni Z-y, Hu Y, Liang W-h, Ou C-q, He J-x, et al. Clinical Characteristics of Coronavirus Disease 2019 in China. New England Journal of Medicine. 2020;382(18):1708-20.

https://doi.org/10.1056/NEJMoa2002032 
5. World Health Organization. Director-General's opening remarks at the media briefing on COVIDig. (Online Article). Available from: https://www.who.int/directorgeneral/speeches/detail/who-director-general-sopening-remarks-at-the-media-briefing-on-covid-19--11-march-2020. [Last Accessed on $11^{\text {th }}$ March, 2021 ]

6. Prime Ministers Office (PMO) $\mathrm{MoH}$, Royal Government of Bhutan, Bhutan. [Last Accessed on $14^{\text {th }}$ February, 2021]

7. Chan JFW, Yuan S, Kok K-H, To KK-W, Chu H, Yang $\mathrm{J}$, et al. A familial cluster of pneumonia associated with the 2019 novel coronavirus indicating person-to-person transmission: a study of a family cluster. The Lancet. 2020;395(10223):514-23. https://doi.org/10.1016/So1406736(20)30154-9

8. Lotfi M, Hamblin MR, Rezaei N. COVID-19: Transmission, prevention, and potential therapeutic opportunities. Clinica Chimica Acta. 2020;508:254-66. https://doi.org/10.1016/j.cca.2020.05.044

9. World Health Organization. WHO save lives: clean your hands in the context of COVID-19. (Online Article). Available from: https://www.who.int/campaigns/world-hand-hygieneday. [Last Accessed on $14^{\text {th }}$ March, 2021] 1o. Haq NU, Hassali MA, Shafie AA, Saleem F, Farooqui $M$, Aljadhey $H$. A cross sectional assessment of knowledge, attitude and practice towards Hepatitis B among healthy population of Quetta, Pakistan. BMC Public Health. 2012;12:692. https://doi.org/10.1186/14712458-12-692

11. World Health Organization. Coronavirus disease (COVID-19): How is it transmitted?. (Online Article). Available from: https://www.who.int/news-room/q-adetail/coronavirus-disease-covid-19-how-is-ittransmitted. [Last Accessed on $14^{\text {th }}$ March, 2021]
12. Lin Y, Huang L, Nie S, Liu Z, Yu H, Yan W, et al. Knowledge, Attitudes and Practices (KAP) related to the Pandemic $\left(\mathrm{H}_{1} \mathrm{~N}_{1}\right) 2009$ among Chinese General Population: a Telephone Survey. BMC Infectious Diseases. 2011;11:128. https://doi.org/10.1186/1471-233411-128

13. Zhong B-L, Luo W, Li H-M, Zhang Q-Q, Liu X-G, Li $\mathrm{W}$-T, et al. Knowledge, attitudes, and practices towards COVID-19 among Chinese residents during the rapid rise period of the COVID-19 outbreak: a quick online cross-sectional survey. Int J Biol Sci. 2020;16(10):174552. https://doi.org/10.715o/ijbs.45221

14. Sarfaraz S, Shabbir J, Mudasser MA, Khurshid Z, AlQuraini AAA, Abbasi MS, et al. Knowledge and Attitude of Dental Practitioners Related to Disinfection during the COVID-19 Pandemic. Healthcare (Basel). 2020;8(3):232.

https://doi.org/10.3390/healthcare8030232

15. Khan AM, Nawabi S, Javed MQ. Dental Faculty's Knowledge and Attitude regarding COVID-19 disease in Qassim, Saudi Arabia. Medico Legal Update. 2020;20(4)1202-10.

https://doi.org/10.37506/mlu.v2oi4.1991

16. Kamate S, Sharma S, Thakar S, Srivastava D, Sengupta K, Hadi A, et al. Assessing Knowledge, Attitudes and Practices of dental practitioners regarding the COVID-19 pandemic: A multinational study. Dental and medical problems. 2020;57:11-7. https://doi.org/10.17219/dmp/119743

17. Acharya A, Thapa, P, Shrestha R, Shrestha S, Gupta A. Knowledge, attitude and practice of Nepali medical and dental practitioners on infection control during Covid-19 Pandemic. Orthodontic Journal of Nepal 2020;10(2):29-35.

https://doi.org/10.3126/ojn.v1oi2.31065

18. Ministry of Health, Royal Government of Bhutan, Bhutan. 2020.

\section{AUTHOR AFFILIATIONS: ${ }^{*}$ Corresponding Author)}

1. Jigme Dorji Wangchuck National Referral Hospital, Thimphu Bhutan.

2. Gidakom Hospital, Ministry of Health, Thimphu Bhutan (https://orcid.org/oooo-0oo3-4421-7378). 